\title{
Klotho Reduces Necroptosis by Targeting Oxidative Stress Involved in Renal Ischemic-Reperfusion Injury
}

\author{
Yingying Qian Xiangjiang Guo Lin Che Xuejing Guan Bei Wu Renhua Lu \\ Mingli Zhu Huihua Pang Yucheng Yan Zhaohui Ni Leyi Gu
}

Department of Nephrology, Molecular Cell Lab for Kidney Disease, Renji Hospital, School of Medicine, Shanghai Jiao Tong University, Shanghai, China

\section{Key Words}

Klotho $・$ Necroptosis $•$ Oxidative stress $•$ AKI $•$ Ischemic-reperfusion injury

\begin{abstract}
Background/Aims: Klotho is a multifunctional protein expressed predominantly in kidney tubular epithelium. Here, we investigated the protective effects of Klotho on necroptosis in renal ischemic-reperfusion injury (IRI) and the role of oxidative stress in this process. Methods: Mice were subjected to bilateral renal pedicle clamping. Mouse renal tubular epithelial (TCMK1) cells were exposed to hypoxia/reoxygenation ( $\mathrm{H} / \mathrm{R})$ or $\mathrm{H}_{2} \mathrm{O}_{2}$. Kidney samples from acute kidney injury (AKI) patients and controls were examined by immunofluorescence. Klotho protein and $\mathrm{N}$-acetyl-L-cysteine (NAC) were used to define their roles in mediating necroptosis. Necroptosis was assessed by TUNEL staining, immunoblotting, and real-time PCR. Oxidative stress was studied via ELISA, immunoblotting, colorimetric, and thiobarbituric acid reactive substances assays. Results: Renal IRI induced Klotho deficiency in the serum and kidney, but an increase in the urine. The levels of the necroptotic markers receptor-interacting protein kinase (RIP) 1, RIP3, IL-1 $\beta$, and TUNEL-positive cells increased after IRI; all increases were ameliorated by Klotho. In TCMK-1 cells, Klotho and NAC attenuated the elevation in RIP1, RIP3, and LDH release induced by $\mathrm{H} / \mathrm{R}$ or $\mathrm{H}_{2} \mathrm{O}_{2}$. Moreover, Klotho decreased the levels of oxidative stress biomarkers and elevated superoxide dismutase 2 expression in both in vivo and in vitro experiments. Studies in human samples further confirmed the Klotho deficiency and increased formation of RIP3 puncta in AKI kidneys. Conclusion: Klotho protects tubular epithelial cells from IRI and its anti-necroptotic role may be associated with oxidative stress inhibition.




\section{Introduction}

Acute kidney injury (AKI) is a common and serious disorder associated with considerably high morbidity and mortality $[1,2]$. It affects about 1 in 5 hospitalized patients worldwide and has mortality rates of $23.9 \%$ in adults and $13.8 \%$ in children [3]. Moreover, it has become increasingly clear that AKI is a risk factor for chronic or end-stage renal disease even in patients whose renal function seems to completely recover following an episode of AKI [4-6]. The poor outcomes can be attributed to both delayed diagnosis relying on serum creatinine (Scr) and few optimal therapeutic treatments.

In contrast to apoptosis, necrosis has been long recognized as an accidental cell death, with histological features of cell swelling and rupture, and is thus unlikely to be pharmacologically targeted. Recent research has provided insights into regulated necrosis, a new mode of cell death similar to necrosis in morphology but orchestrated [7]. Necroptosis, one of the well-documented forms of regulated necrosis [8], requires the formation of a necroptosome containing receptor-interacting protein kinase (RIP) 1 and RIP3 [9, 10]. Necroptosis has been observed in various tissue injury, including heart [11, 12], brain [13], and kidney [14]. However, the trigger for necroptosis in AKI is currently unclear.

Klotho was originally identified as an anti-aging gene [15]. Klotho protein, or more precisely $\alpha$-Klotho, comprises membrane-bound full-length Klotho and soluble Klotho [16]. Recently, some studies have shown that the kidney has the highest level of Klotho expression, and the kidney is also the principal organ mediating Klotho homeostasis $[17,18]$. Increasing evidence has shown low Klotho levels in the serum and kidney during AKI or chronic kidney disease (CKD) [19-21]. These data indicate a relationship between Klotho deficiency and conditions that exacerbate renal damage. Klotho administration or overexpression can be renoprotective [22-24]. However, the underlying mechanism remains largely unknown and it is unclear whether Klotho has any protective effect on necroptosis in renal ischemicreperfusion injury (IRI).

Here, we confirmed that AKI is a state of Klotho deficiency accompanied by enhanced oxidative stress and necroptosis. We then explored the protective effect of Klotho on the necroptosis involved in renal IRI. We also uncovered the critical contribution of reactive oxygen species (ROS) to triggering necroptosis in tubular epithelial cells, which can be abolished by Klotho.

\section{Materials and Methods}

\section{Human study}

A total of 10 patients with AKI identified by the AKIN definition [25] were enrolled for this study from the Department of Nephrology in Renji Hospital, School of Medicine, Shanghai Jiaotong University, Shanghai, China. Kidney biopsy samples were obtained. Normal kidney tissues $(n=5)$ were collected from surgical samples of nephrectomy for renal hamartoma. The ethics review board of Renji Hospital, Shanghai Jiaotong University School of Medicine, approved this study. All patients received an explanation of the study and provided written informed consent prior to enrollment.

\section{Animal model}

All procedures were conducted according to protocols based on the National Institutes of Health Guide for the Care and Use of Experimental Animals and approved by Renji Hospital, Shanghai Jiaotong University School of Medicine. A total of 150 BALB/c male mice aged 6-8 weeks with a body weight of 20-25 g were used. The IRI-induced AKI model was generated as described previously [26]. Briefly, after anesthetization induced by intraperitoneal injection of $50 \mathrm{mg} / \mathrm{kg}$ pentobarbital, ischemia was induced by bilateral renal artery and vein clamping using nontraumatic vascular clamps for $35 \mathrm{~min}$ at $37^{\circ} \mathrm{C}$. After removal of the clamps, kidneys were inspected for reperfusion based on color change. In the sham group, the renal pedicle was isolated without being clamped. The mice were sacrificed at predetermined time points after reperfusion, and the blood, urine, and kidneys were collected for analysis. Blood and urine 


\section{Cellular Physiology Cell Physiol Biochem 2018;45:2268-2282

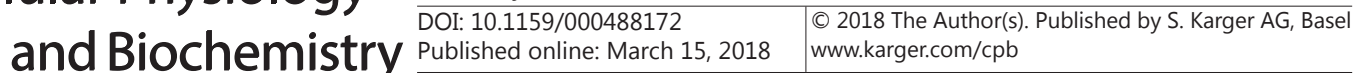 \\ Quian et al.: Klotho Reduces Necroptosis}

samples were centrifuged at $3000 \mathrm{rpm}$ for $10 \mathrm{~min}$, and the supernatants were aliquoted and frozen at -80 ${ }^{\circ} \mathrm{C}$. For the therapeutic investigation, a single dose of recombinant Klotho protein $(360 \mathrm{ng} / 25 \mathrm{~g}$ body weight; R\&D Systems, Inc., Minneapolis, MN) or nec-1 (1.65 mg/kg body weight; Sigma-Aldrich, St. Louis, MO) was intraperitoneally applied at $30 \mathrm{~min}$ or $0 \mathrm{~min}$ of reperfusion, respectively.

\section{Cell culture}

The TCMK-1 (murine tubular epithelial cells) and human kidney 2 (HK2) (proximal tubular cells) cell lines were obtained from the American Type Culture Collection (ATCC; Manassas, VA). Cells were cultured in Dulbecco's modified Eagle's medium/F12 (Thermo Scientific, Rockford, IL) supplemented with 10\% fetal bovine serum (Thermo Scientific) at $37^{\circ} \mathrm{C}$ in $5 \% \mathrm{CO}_{2}$. For H/R research, confluent TCMK-1 or HK2 cells were incubated under hypoxic conditions $\left(1 \% \mathrm{O}_{2}, 94 \% \mathrm{~N}_{2}\right.$, and $5 \% \mathrm{CO}_{2}$ ) in a controlled hypoxic chamber (Thermo Scientific) for $24 \mathrm{~h}$, and then removed or not to a normoxic incubator for reoxygenation. Normoxic controls were cultured under normoxic conditions $\left(21 \% \mathrm{O}_{2}, 5 \% \mathrm{CO}_{2}, 74 \% \mathrm{~N}_{2}\right)$ for identical times. For the $\mathrm{H}_{2} \mathrm{O}_{2}$ study, confluent TCMK-1 cells were exposed or not to $\mathrm{H}_{2} \mathrm{O}_{2}$ at different doses for $24 \mathrm{~h}$. In certain experiments, cells were pre-administered different doses of recombinant Klotho protein or $30 \mu \mathrm{M} \mathrm{N}$-acetylcysteine (NAC; Sigma-Aldrich) for $1 \mathrm{~h}$.

\section{Assessment of membrane integrity}

Measurement of the release of LDH was performed by using the CytoTox-ONE ${ }^{\mathrm{TM}}$ assay according to the manufacturer's instructions (Promega, Madison, WI). Fluorescence was recorded using a fluorescence plate reader (BioTek-synergy, Arcugnano, Vicenza) with an excitation wavelength of $560 \mathrm{~nm}$ and an emission wavelength of $590 \mathrm{~nm}$.

\section{Immunoblot analysis}

Whole cell or tissue samples were homogenized in RIPA buffer (Santa Cruz Biotechnology, Inc., Dallas, TX) with protease inhibitor cocktail (Thermo Scientific) and $40 \mu \mathrm{g}$ total protein was used for immunoblot analysis according to our previous protocols [27]. Blots were probed with anti-Klotho (1:200; Thermo Scientific), anti-3-nitrotyrosine (1:500; Abcam, Cambridge), anti-SOD2 (1:500; Santa Cruz Biotechnology), anti-RIP1 (1:100; Santa Cruz Biotechnology), anti-RIP3 (1:500; Santa Cruz Biotechnology), anti-IL-1 beta (1:1000; Abcam), anti-tubulin (1:1000; Abcam), anti-beta-actin (1:2000; Abcam), anti-catalase (1:1000; Abcam), anti-GPX4 (1:1000; Abcam), anti-t-FoxO1 (1:1000; Cell Signaling Technology, Beverly, CA), antip-Fox01 (1:1000; Cell Signaling Technology), anti-t-Fox03a (1:1000; Cell Signaling Technology), anti-pFox03a (1:1000; Cell Signaling Technology), or anti-GAPDH (1:1000; Cell Signaling Technology) antibodies overnight at $4{ }^{\circ} \mathrm{C}$. After washing, the membranes were incubated with the appropriate horseradish peroxidase-conjugated secondary antibody (1:5000; Cell Signaling Technology). After washing, specific signals were determined using an ECL kit (Thermo Scientific) on a Tanon 5200 Chemiluminescent Imaging System (Tanon, Shanghai). Gray values were analyzed with Image software.

\section{RNA extraction and quantitative real-time PCR}

Total mRNA was extracted with Trizol Reagent (Thermo Scientific) and reverse transcribed with cDNA Reverse Transcription Kits (TAKARA, Dalian). Target or control genes were amplified with specific primers (Table 1) and SYBR Green I reagent (TAKARA) on a thermocycler (LightCycler 480 System; Roche Applied Science, Mannheim). Samples were run in triplicate for initial denaturation at $95^{\circ} \mathrm{C}$ for $30 \mathrm{~s}$ followed by 40 cycles at $95{ }^{\circ} \mathrm{C}$ for $5 \mathrm{~s}$ and $60^{\circ} \mathrm{C}$ for $20 \mathrm{~s}$. The amounts of different mRNA transcripts were calculated by the comparative $\mathrm{C}_{\mathrm{T}}$ method [28] and corrected for GAPDH.

Table 1. Primers for real-time PCR

\begin{tabular}{|c|c|}
\hline Gene & Primer Sequence \\
\hline \multirow[t]{2}{*}{ klotho } & Forward: 5'-TCTCAAGAAGTTCATAATGGAAACC-3' \\
\hline & Reverse: 5'-CAGAAAGTCAACGTAGAAGAGTCCT-3' \\
\hline \multirow[t]{2}{*}{ gapdh } & Forward: 5'-CCAATGTGTCCGTCGTGGATCT-3' \\
\hline & Reverse: 5'-GTTGAAGTCGCAGGAGACAACC-3' \\
\hline \multirow[t]{2}{*}{ rip1 } & Forward: 5'-GACAGACCTAGACAGCGGAG-3' \\
\hline & Reverse: 5'-CCAGTAGCTTCACCACTCGAC-3' \\
\hline \multirow[t]{2}{*}{ rip3 } & Forward: 5'-GGCACCCTAGCGTACTTGG-3' \\
\hline & Reverse: 5'-GCTGTAGACATCACTCGCTTT-3' \\
\hline \multirow[t]{2}{*}{ il-1 beta } & Forward: 5'-TTCAGGCAGGCAGTATCACTC-3' \\
\hline & Reverse: 5'-GAAGGTCCACGGGAAAGACAC-3' \\
\hline \multirow[t]{2}{*}{ fgf23 } & Forward: 5'- ATGCTAGGGACCTGCCTTAGA-3' \\
\hline & Forward: 5'- AGCCAAGCAATGGGGAAGTG -3' \\
\hline
\end{tabular}




\section{Cellular Physiology Cell Physiol Biochem 2018;45:2268-2282 \begin{tabular}{l|l} 
and Biochemistry Published online: March 15, 2018 & $\begin{array}{l}\text { (c) } 2018 \text { The Author(s). Published by S. Karger AG, Basel } \\
\text { www.karger.com/cpb }\end{array}$
\end{tabular}}

ELISA

Mouse Klotho ELISA (Uscn Life Science, Wuhan) and u-8-OHdG ELISA (JaICA, Fukuroi, Shizuoka) were performed according to the manufacturer's instructions. The intra- and inter-assay coefficients of variation were both $<12 \%$ for Klotho and $<8 \%$ for $8-0 H d G$. The assay ranges were 3.12 to $200 \mathrm{pg} / \mathrm{mL}$ for Klotho and 0.5 to $200 \mathrm{ng} / \mathrm{mL}$ for 8-OHdG. The results of urinary Klotho and 8-OHdG were corrected for urinary creatinine excretion.

Measurement of total SOD activity and MDA levels

Total SOD activity was determined using a Superoxide Dismutase Activity/Inhibition Assay Kit (EpiGentek, Farmingdale, NY). Quantitative measurement of MDA was performed using a Thiobarbituric Acid Reactive Substances Assay Kit (Cell Biolabs, Inc., San Diego, CA).

\section{Determination of intracellular ROS generation}

A cell-permeable probe, 2',7'-dichlorofluorescein diacetate (DCFH-DA, Beyotime Biotechnology, Jiangsu), was used to measure intracellular ROS formation. Briefly, cells were incubated with DCFH-DA $(2 \mu \mathrm{M})$ for $20 \mathrm{~min}$ at $37^{\circ} \mathrm{C}$. After washing with serum-free medium, cells were imaged on a fluorescence microscope at $488 \mathrm{~nm}(\times 400$; Leica, Bensheim, Germany).

In situ TUNEL assays

To detect DNA strand breaks in kidney tissues, TUNEL staining was performed using an In Situ Cell Death Detection Kit (Roche Applied Science). Samples were analyzed under a fluorescence microscope (×200; Leica).

\section{Histochemistry and immunofluorescent staining}

Kidneys were fixed in $4 \%$ neutral-buffered formaldehyde for $24 \mathrm{~h}$, dehydrated, and embedded in paraffin. Sections $(4 \mu \mathrm{m})$ were stained with hematoxylin-eosin (HE). The histologic damage was scored by two pathologists who were blinded to the experimental conditions. The scoring system was described previously [29]. Immunohistochemistry staining was performed with primary antibodies against Klotho (1:100) and Kim-1 (1:100; Abcam), followed by biotinylated secondary antibody incubation. After incubation with Vector ABC reagent, the slides were developed with DAB substrate (Vector Laboratories, Youngstown, $\mathrm{OH})$. For nuclear staining, Carazzi hematoxylin was used. Stained sections were analyzed on a microscope $(\times 200$; Leica). For immunofluorescent staining, primary antibodies against Klotho (1:100), SOD2 (1:100), RIP3 (1:100), Kim-1 (1:100), and fluorescent-conjugated secondary antibodies (1:200) were applied to the sections. Stained sections were analyzed on a microscope $(\times 200$ and $\times 400$; Leica).

\section{Statistical analyses}

SPSS version 21.0 statistical software (IBM SPSS, Chicago, IL) was used for statistical analysis. Data are expressed as the mean \pm SEM and compared using one-way ANOVA followed by Tukey multiple comparison tests when they were normally distributed. Non-normally distributed continuous data were expressed as medians with interquartile range and analyzed using the Mann-Whitney U test. The Spearman's correlation coefficient was examined for correlation analysis. Significant differences were considered as $p<0.05$.

\section{Results}

\section{Klotho decreases after renal IRI}

After renal IRI, the levels of Scr and blood urea nitrogen (BUN) significantly increased at $24 \mathrm{~h}$ of reperfusion (Scr: $95.20 \pm 9.66 \mu \mathrm{mol} / \mathrm{L} v s .11 .20 \pm 0.86 \mu \mathrm{mol} / \mathrm{L}$; BUN: $40.96 \pm 2.79$ $\mathrm{mmol} / \mathrm{L} \mathrm{vs.} 7.86 \pm 1.00 \mathrm{mmol} / \mathrm{L}$; both $p<0.001$ ) and completely returned to normal levels on day 7 compared with sham-operated mice (Fig. 1A). The histological results showed increased levels of renal tubular damage and kidney injury molecule 1 (Kim-1) expression after renal IRI (Fig. 1B and C).

Klotho concentrations in the serum of IRI mice increased immediately post-reperfusion $(0 \mathrm{~h})$, but then significantly declined at $5 \mathrm{~h}$, reached the lowest level at $24 \mathrm{~h}(669.89 \pm 61.05$ 
Fig. 1. Klotho levels are decreased in the serum and kidney but increased in the urine after IRI. Mice were divided into IRI and sham groups and sacrificed at $0 \mathrm{~h}$ to 7 days post-reperfusion. (A) Scr and BUN concentrations. (B) Representative kidney sections stained with HE $(\times 200)$ and its semiquantification to represent renal tubular damage on day 1 and day 7 post-reperfusion. (C) Representative immunohistochemistry $(\times 200)$ for Kim-1 protein in the kidneys on day 1 postreperfusion. (D) Serum Klotho concentrations at pre-surgery and $0 \mathrm{~h}$ to 7 days after reperfusion. (E) Urinary Klotho concentrations at pre-surgery and $12 \mathrm{~h}$ to 7 days after reperfusion. Data are corrected by urinary creatinine. (F) Klotho transcripts in the kidneys. Representative (G) immunoblot and $(\mathrm{H})$ immunohistochemistry $(\times 200)$ for Klotho protein in the kidneys on day 1 post-reperfusion and summary of the western blot data $(n=5)$. Bars represent the mean \pm SEM (n $=5$ per group). ${ }^{*} \mathrm{p}<0.05,{ }^{* *} \mathrm{p}<0.01$, and ${ }^{* * *} \mathrm{p}<0.001$ vs. sham group. \#\#\# $\mathrm{p}<0.001$ between AKI mice on day 1 and day 7 post-IRI. Arrows indicate labeled Klotho protein in

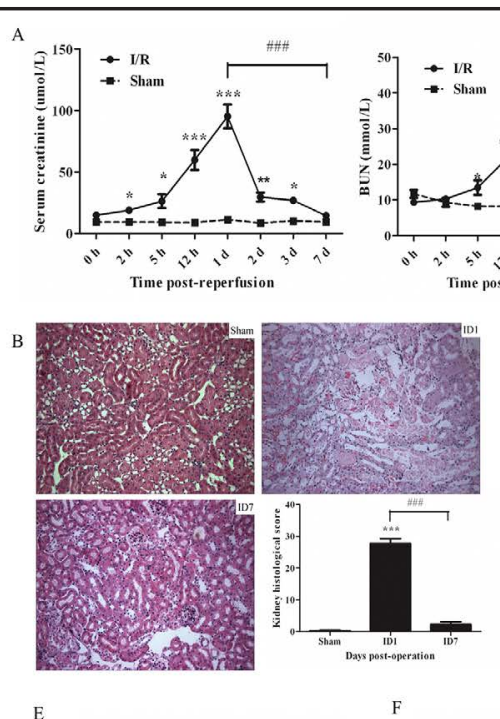

E
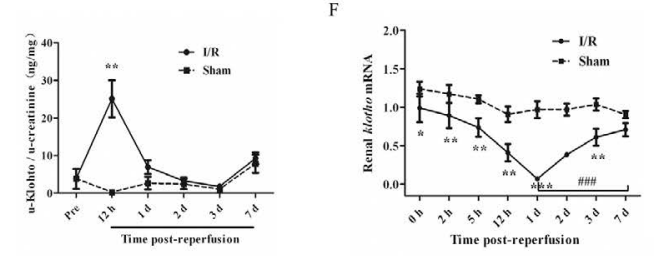

G
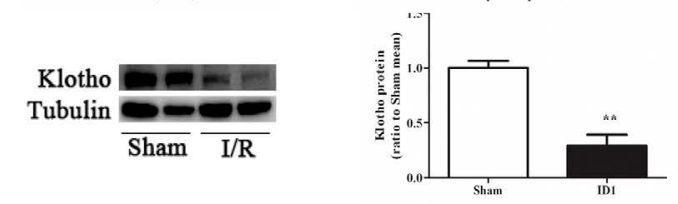

$\mathrm{H}$

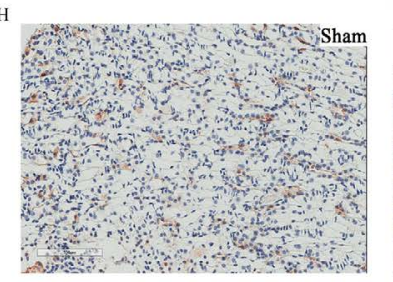

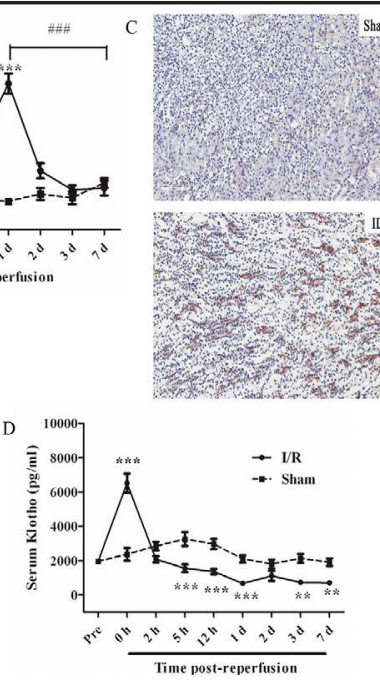

the tubular lumen.

$\mathrm{pg} / \mathrm{mL} v s .2093 .44 \pm 213.20 \mathrm{pg} / \mathrm{mL}, p<0.001)$, and remained lower than that of sham mice on day 7 (703.71 $\pm 52.18 \mathrm{pg} / \mathrm{mL}$ vs. $1902.73 \pm 221.99 \mathrm{pg} / \mathrm{mL}, p<0.01 ;$ Fig. 1D). In contrast to serum Klotho, urinary Klotho levels were significantly elevated at $12 \mathrm{~h}$ post-reperfusion in IRI mice and returned to normal soon afterward (Fig. 1E). In addition, Klotho mRNA and protein expression in the kidney were also downregulated in the IRI group (Fig. 1F and $\mathrm{G})$. Moreover, Klotho was increased in the tubular lumen of AKI mice but was decreased in kidney tubular epithelial cells (Fig. 1H).

\section{Klotho administration attenuates IRI-induced AKI}

To clarify the therapeutic effects of Klotho in IRI-induced AKI, recombinant Klotho protein or phosphate-buffered saline was applied intraperitoneally $30 \mathrm{~min}$ after reperfusion. Serum Klotho levels in Klotho-treated mice significantly increased on 1 day after injection and were higher than those in vehicle-treated mice for at least 2 days (Fig. 2A). As shown in Fig. 2B and C, Klotho treatment significantly attenuated the increase in Scr and BUN induced by IRI. Histological kidney damage and Kim-1 expression were also alleviated in Klotho-treated IRI mice (Fig. 2D and E). We then investigated if fibroblast growth factor (FGF) 23 promoted 


\section{Cellular Physiology and Biochemistry}

similar effects on renal IRI. As shown in Fig. 2F, no significant differences in FGF23 transcripts were found between sham and IRI mice or between Klotho-treated and non-treated IRI mice.

\section{Necroptosis is} involved in renal IRI

As shown in Fig. $3 \mathrm{~A}$ and $\mathrm{B}$, IRI kidney overproduced RIP1 and RIP3. Necroptosis can be distinguished from apoptosis by the rupture of the plasma membrane and subsequent release of its intracellular contents, leading to a greater capacity to promote immune responses [30]. Therefore, we further assessed the expression of IL-1 beta and found that it was significantly increased in AKI mice (Fig. $3 \mathrm{C}$ and D). In addition, necrostatin-1 (Nec-1), a necroptosis inhibitor, prevented renal dysfunction in IRI mice (Fig. 3E). Histological

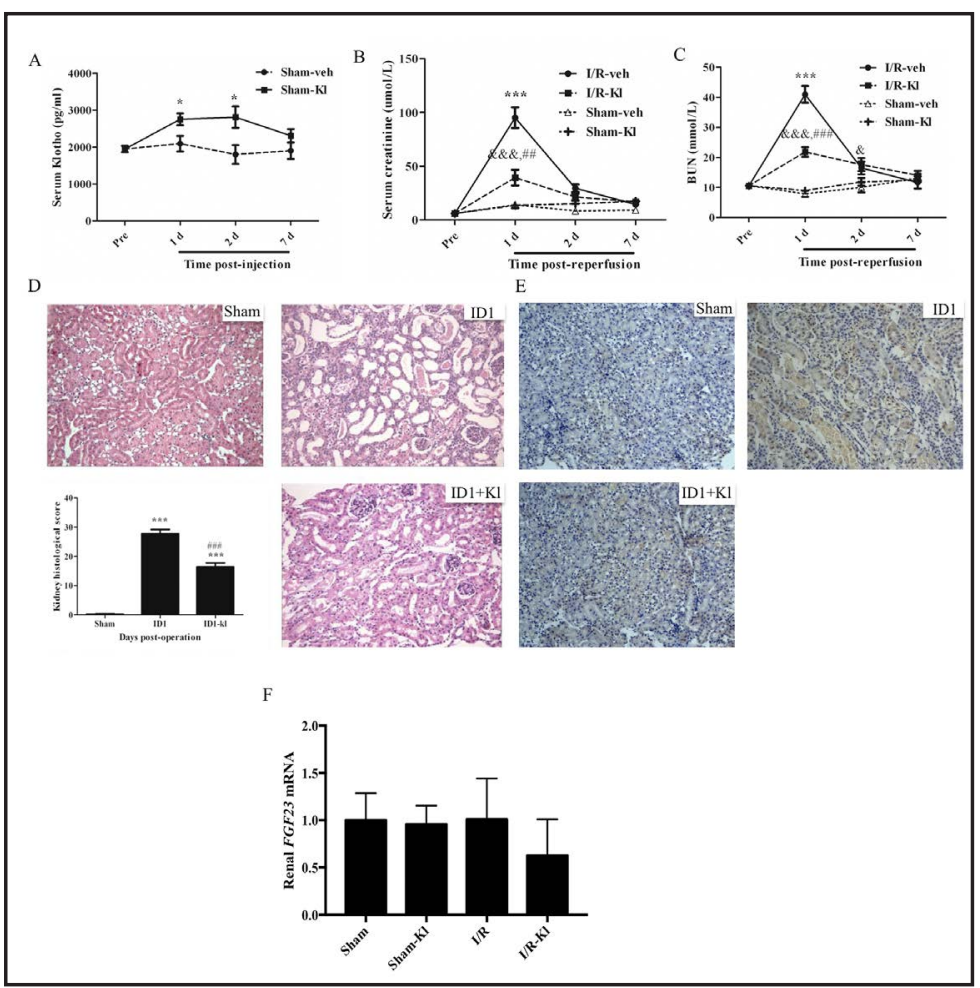

Fig. 2. Klotho treatment alleviates IRI-induced AKI. AKI and sham mice with or without Klotho treatment were sacrificed pre-operatively and 1, 2, and 7 days after reperfusion. (A) Serum Klotho levels after Klotho or vehicle injection. (B) Scr and (C) BUN concentrations. (D) Representative kidney sections stained with HE $(\times 200)$ on day 1 post-reperfusion and its semiquantification to represent renal tubular damage. (E) Representative immunohistochemistry $(\times 200)$ for Kim-1 protein in the kidneys on day 1 . (F) FGF23 transcripts in the kidneys. Bars represent the mean \pm SEM (n $=5$ per group). ${ }^{*} \mathrm{p}<0.05$ and ${ }^{* * *} \mathrm{p}<0.001$ vs. sham-veh group. ${ }^{*} \mathrm{p}<0.05$ and ${ }^{\& \& \&} \mathrm{p}<0.001$ vs. sham-Kl group. ${ }^{\# \#} \mathrm{p}<0.01$ and ${ }^{\# \# \#} \mathrm{p}<0.001$ vs. IRI-veh mice. examination further showed fewer features of kidney damage after Nec-1 treatment in IRI mice (Fig. 3F).

Klotho reduces the necroptosis induced by renal IRI

Because TUNEL positivity is not only limited to apoptosis, but also found in necroptosis $[31,32]$, we conducted TUNEL staining on 1 day after reperfusion. As shown in Fig. 4A, the number of TUNEL-positive cells was higher in IRI mice than in sham mice and was attenuated after Klotho treatment. Klotho also downregulated the expression of RIP1, RIP3, and IL-1 beta in IRI mice (Fig. 4B-D).

In vitro with TCMK-1 cells, hypoxia for $24 \mathrm{~h}$ followed by reoxygenation for $8 \mathrm{~h}$ induced Klotho deficiency and IL-1 beta elevation (Fig. 4E). As shown in Fig. 4F and G, hypoxia/ reoxygenation (H/R) upregulated the expression of RIP1 and RIP3 and induced the release of lactate dehydrogenase (LDH). However, Klotho and N-acetyl-L-cysteine (NAC), a ROS scavenger, attenuated this response. In addition to TCMK-1 cells, Klotho also decreased RIP1 and RIP3 elevation in human proximal renal tubular epithelial cells (HK2) in response to H/R (Fig. 4H).

Klotho ameliorates the oxidative stress implicated in renal IRI

As demonstrated in Fig. 5A, renal malondialdehyde (MDA) concentrations significantly increased to nearly 2 -fold those of sham-operated mice after ischemic injury. MDA levels 
in IRI mice remained higher than those in the sham group after 7 days postIRI, although renal function had completely recovered. Urinary 8-hydroxy-2'deoxyguanosine (8-OHdG) levels increased after IRI, reached the highest levels on day 1 , and finally recovered to the baseline levels by day 7 (Fig. 5B). Conversely, the activities of total superoxide dismutase (SOD) and the expression of SOD2 protein in IRI kidneys were downregulated (Fig. 5C and D). Both serum Klotho protein and renal Klotho transcripts were negatively correlated with the levels of urinary 8-OHdG and were positively correlated with total SOD activities $(p<0.05$; Fig. 5E and F). A negative correlation was also found between renal

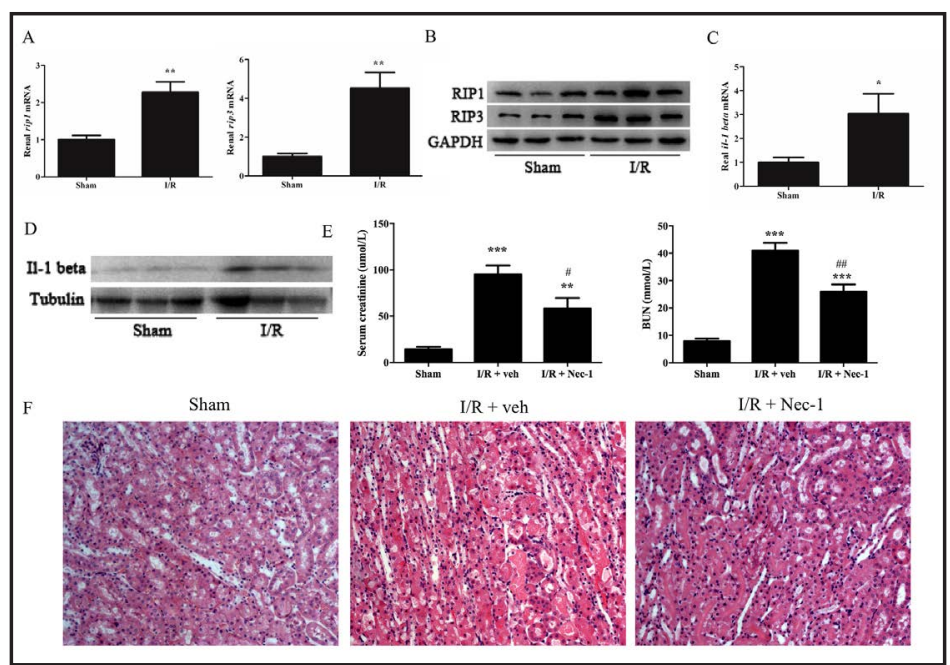

Fig. 3. Necroptosis contributes to renal IRI. AKI and sham mice were killed at $24 \mathrm{~h}$ post-reperfusion. (A) RIP1 and RIP3 transcripts. (B) Representative immunoblot for RIP1 and RIP3 proteins in the kidneys. (C) IL-1 beta transcripts. (D) Representative immunoblot for IL-1 beta proteins in the kidneys. For therapeutic research, nec-1 was intraperitoneally applied at $0 \mathrm{~min}$ of reperfusion. Mice were killed at $24 \mathrm{~h}$ postreperfusion. (E) Scr and BUN concentrations. (F) Representative HEstained kidney sections $(\times 200)$. Bars represent the mean \pm SEM $(n=5$ mice per group per time point). ${ }^{*} \mathrm{p}<0.05,{ }^{* *} \mathrm{p}<0.01$, and ${ }^{* * *} \mathrm{p}<0.001$ vs. sham group. ${ }^{\#} \mathrm{p}<0.05$ and ${ }^{\# \#} \mathrm{p}<0.01$ vs. IRI-veh group.

Klotho transcripts and renal

MDA but not between serum Klotho and renal MDA (Fig. 5G).

Klotho application partly but significantly mitigated the generation of $\mathrm{u}-8-\mathrm{OHdG}$ and renal MDA in IRI mice (Fig. 6A and B). Immunoblot results showed that the kidneys had lower 3-nitrotyrosine (3-N) and higher SOD2 expression in Klotho-treated IRI mice than in vehicle-treated IRI mice (Fig. 6C and D). Klotho also ameliorated the reduction in total SOD activities induced by IRI (Fig. 6E). In line with the in vivo results, exposure of TCMK-1 cells to hypoxia resulted in an enormous generation of ROS and more ROS production during reoxygenation. In contrast, Klotho application at $4 \mathrm{nM}$ effectively decreased hypoxia or H/R-induced ROS generation (Fig. 6F). Meanwhile, renal SOD2 expression was higher in the Klotho-treated group than in the H/R group (Fig. 6G). However, only mild changes were found in glutathione-peroxidase (GPX) 4 and catalase protein expression between Klotho-treated and untreated H/R groups (Fig. 6H and I). We further evaluated whether Klotho regulates the signaling of Forkhead box protein 0 transcription factors (FoxOs), which are negatively regulated by phosphorylation. Immunoblot analysis revealed that $\mathrm{H} / \mathrm{R}$ treatment induced Fox01 and Fox03a phosphorylation, whereas Klotho protein reduced their phosphorylation (Fig. 6J).

Klotho reduces the $\mathrm{H}_{2} \mathrm{O}_{2}$-triggered necroptosis in TCMK-1 cells

We then tried to assess the critical role of ROS in regulating necroptosis in tubular epithelial cells and the presumed beneficial effect of Klotho on this process. As shown in Fig. 7A and $\mathrm{B}, \mathrm{H}_{2} \mathrm{O}_{2}$ elevated the expression of RIP1 and RIP3 proteins, downregulated the expression of SOD2 protein, and increased the release of LDH in a dose-dependent manner. In contrast, the expression of RIP1 and RIP3 proteins was downregulated and the release of LDH was decreased by Klotho or NAC (Fig. 7C and D). 


\section{Cellular Physiology and Biochemistry}

Cell Physiol Biochem 2018;45:2268-2282

\begin{tabular}{l|l}
\hline DOI: 10.1159/000488172 & C 2018 The Author(s). Published by S. Karger AG, Basel
\end{tabular}

Quian et al.: Klotho Reduces Necroptosis
Fig. 4. Klotho reduces the necroptosis involved in renal IRI. AKI and sham mice treated with Klotho or vehicle were sacrificed at $24 \mathrm{~h}$ post-reperfusion. (A) Representative TUNEL-stained kidney sections (×200). (B) RIP1 and RIP3 transcripts. Representative immunoblot for (C) RIP1 and RIP3 and (D) IL-1 beta proteins in the kidneys. For the in vitro study, TCMK-1 cells were subjected to 24 h hypoxia followed by (E) 0 to 12 $\mathrm{h}$ or ( $\mathrm{F}$ and $\mathrm{G}) 8 \mathrm{~h}$ reoxygenation. (H) HK2 cells were subjected to $24 \mathrm{~h}$ hypoxia/8 h reoxygenation. Representative immunoblot for (E) Klotho and IL-1 beta proteins and (F and H) RIP1 and RIP3 proteins. (G) LDH release. Bars represent the mean \pm SEM $(n=5$ mice per group or $\mathrm{n}=3$ independent in vitro experiments). ${ }^{* *} \mathrm{p}<0.01$ vs. sham group; ${ }^{\#} \mathrm{p}<0.05$ vs. IRI-veh mice for the in vivo data. ${ }^{* *} \mathrm{p}<0.01$ and ${ }^{* * *} \mathrm{p}<0.001$ vs. control group; ${ }^{\#} \mathrm{p}<0.05$ and ${ }^{\# \#} \mathrm{p}<0.001$ vs. nontreated $H / R$ group for the in vitro data.

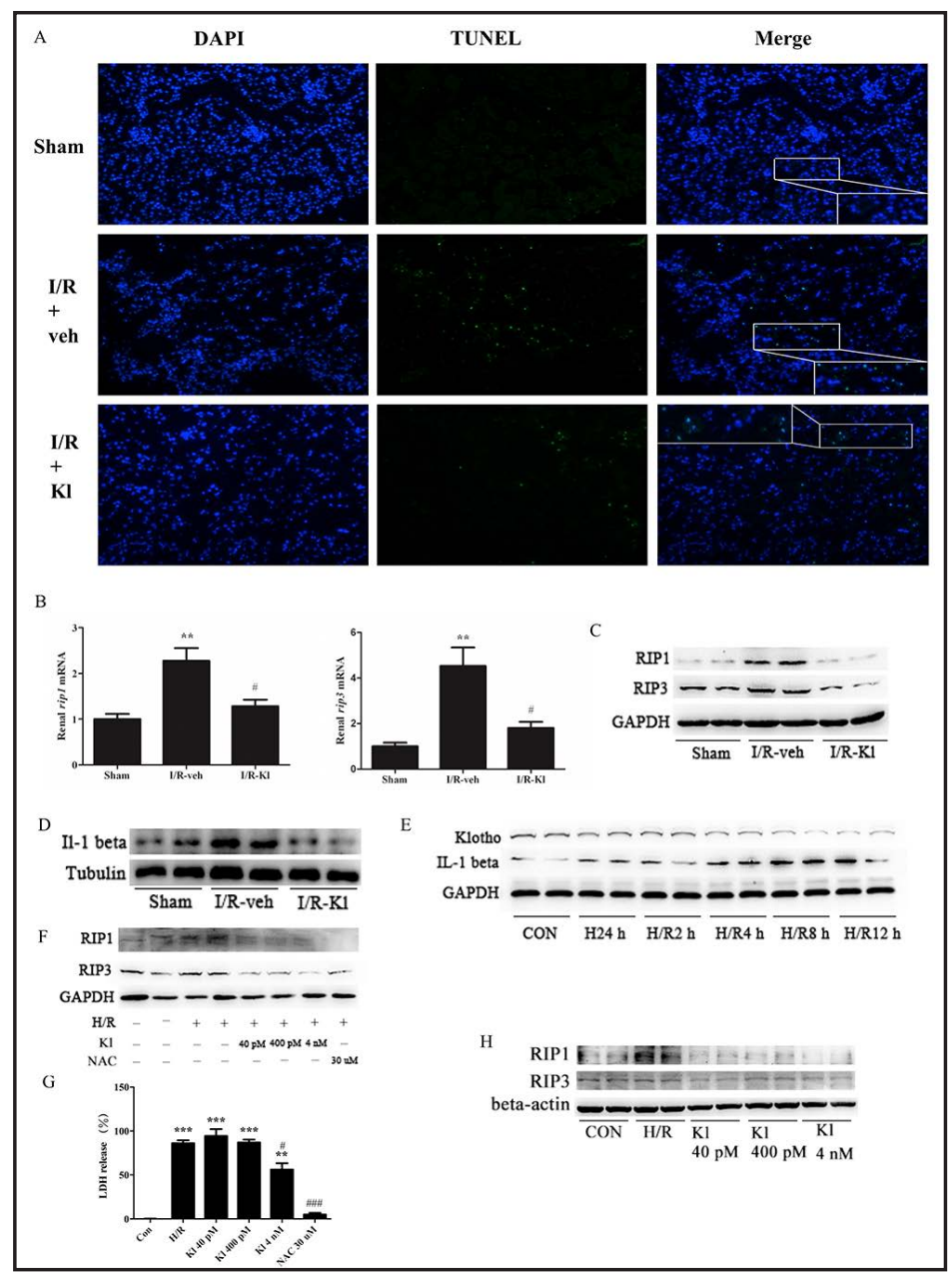

Fig. 5. Oxidative stress is involved in renal IRI. (A) MDA levels in the kidneys. (B) Urinary 8-OHdG concentrations. Urinary samples were collected pre-operatively and 12 $\mathrm{h}$ to 7 days post-reperfusion. (C) Total SOD activity in the kidneys. (D) Representative immunoblot for SOD2 protein in the kidneys on day 1 post-reperfusion. Correlation analyses between Klotho and (E) urinary 8-OHdG, (F) total SOD activities, and (G) renal MDA. The time points were from $12 \mathrm{~h}$ to 7 days post-operation for the correlation between Klotho and urinary $8-\mathrm{OHdG}$ and from $0 \mathrm{~h}$ to 7 days post-operation for the correlation between Klotho and renal MDA or total SOD activities. Bars represent the mean \pm SEM ( $\mathrm{n}=5$ per group). ${ }^{*} \mathrm{p}<0.05,{ }^{* *} \mathrm{p}<0.01$, and ${ }^{* * *} \mathrm{p}<0.001$ vs. sham group; ${ }^{\# \#} \mathrm{p}<0.01$ between AKI mice on day 1 and day 7 post-IRI.

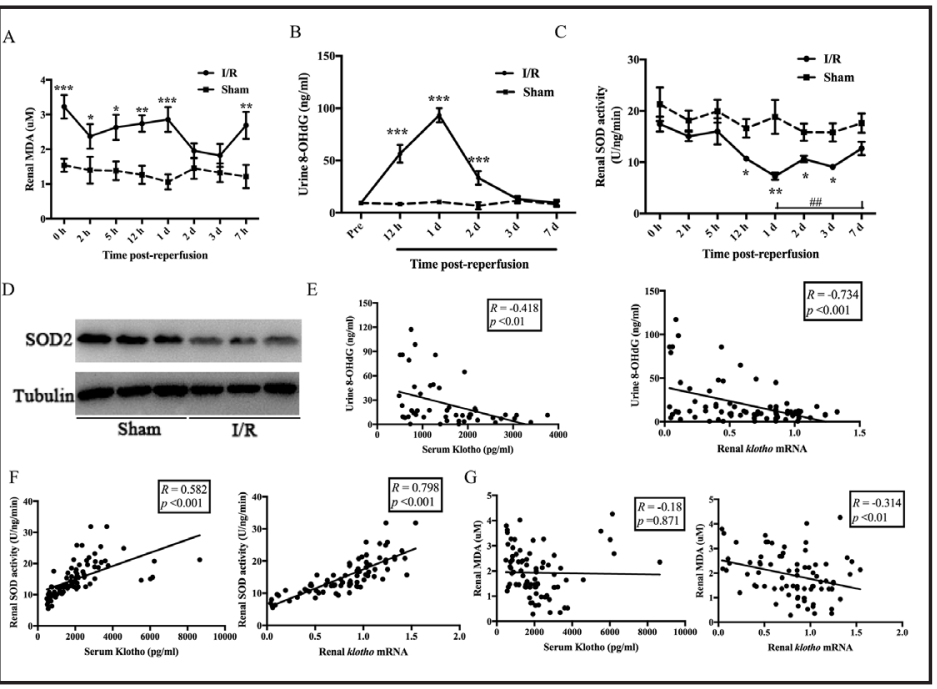


Fig. 6. Klotho inhibits the oxidative stress implicated in renal IRI. AKI and sham mice with or without Klotho treatment were sacrificed pre-operatively and 1, 2, and 7 days after reperfusion. (A) Urinary 8-OHdG concentrations. (B) Renal MDA levels. Representative immunoblot for (C) 3-nitrotyrosine and (D) SOD2 proteins in the kidneys on day 1. (E) Total SOD activity in the kidneys. (F) TCMK-1 cells were exposed to $24 \mathrm{~h}$ hypoxia followed by reoxygenation for 0,4 , and $8 \mathrm{~h}$ in the presence or absence of Klotho protein at $4 \mathrm{nM}$. ROS formation $(\times 400)$ was detected by DCFH-DA staining. ( $G$ and $H$ ) TCMK-1 cells were subjected to $24 \mathrm{~h}$ hypoxia/8 h reoxygenation. Representative immunoblot for (G) SOD2, (H) GPX4, (I) catalase, and (J) FoxO-1 and FoxO3a protein. Bars represent the mean \pm SEM $(n=5$ per group). ${ }^{*} \mathrm{p}<0.05,{ }^{* *} \mathrm{p}<0.01$, and $* * * \mathrm{p}<0.001$ vs. sham-veh group; ${ }^{\&} \mathrm{p}<0.05$ and ${ }^{\& \& \&} \mathrm{p}<0.001$ vs. sham-Kl group; ${ }^{*} \mathrm{p}<0.05$ and ${ }^{\# \# \#} \mathrm{p}<0.001$ vs. IRIveh mice.

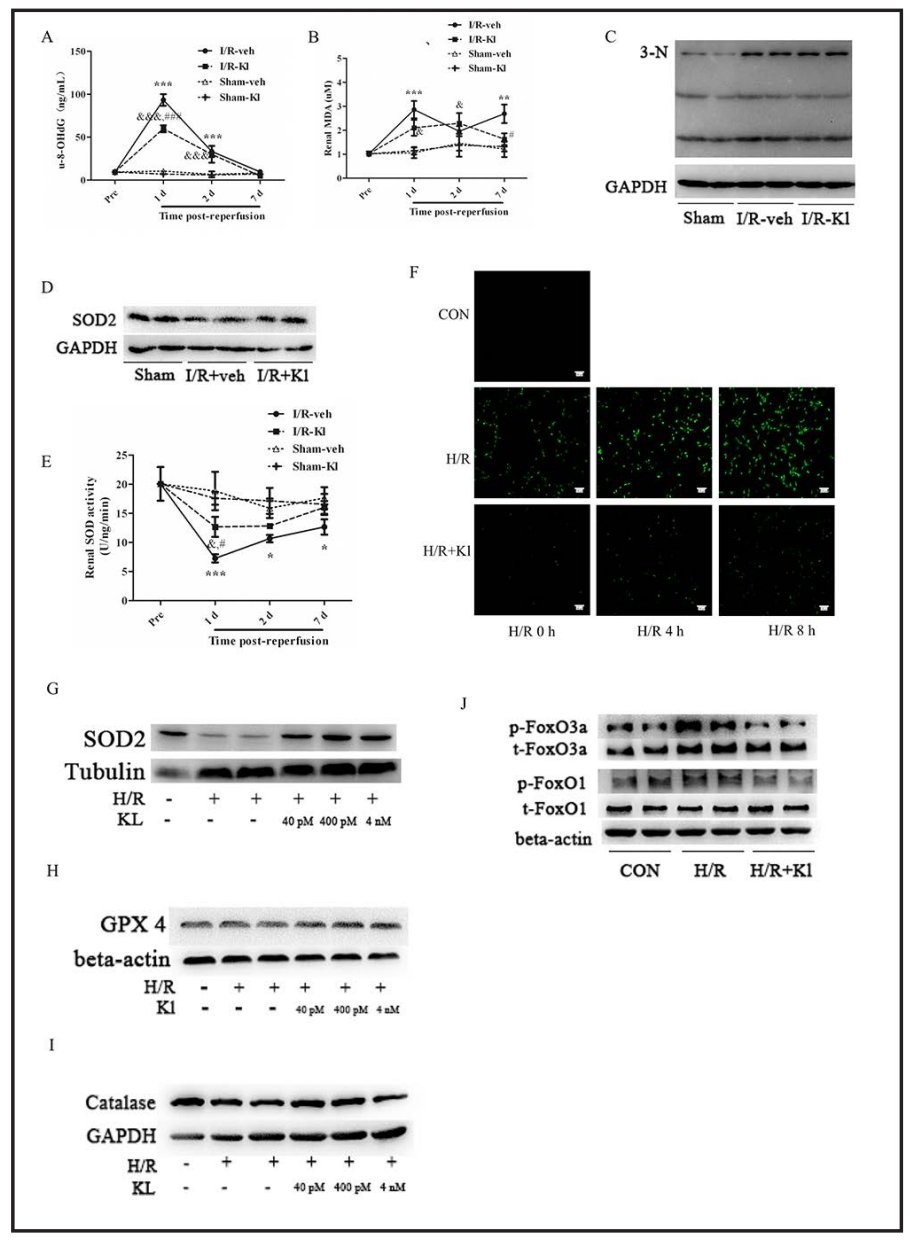

Fig. 7. Klotho mitigates the necroptosis triggered by $\mathrm{H}_{2} \mathrm{O}_{2}$ insult in TCMK-1 cells. In $\mathrm{A}$ and B, TCMK-1 cells were exposed to $\mathrm{H}_{2} \mathrm{O}_{2}$ at different doses for $24 \mathrm{~h}$. (A) Representative immunoblot for RIP1, RIP3, and SOD2 proteins. (B) $\mathrm{LDH}$ release. In $\mathrm{C}$ and $\mathrm{D}$, TCMK-1 cells were exposed to $\mathrm{H}_{2} \mathrm{O}_{2}$ at 300 $\mu \mathrm{M}$ for $24 \mathrm{~h}$. (C) Representative immunoblot for RIP1 and RIP3 proteins. (D) $\mathrm{LDH}$ release. NAC was applied at $30 \mu \mathrm{M}$. Bars represent the mean $\pm \operatorname{SEM}(n=3)$. ${ }^{*} \mathrm{p}<0.05,{ }^{* *} \mathrm{p}<0.01$, and ${ }^{* * *} \mathrm{p}<0.001$ vs. control group; ${ }^{\#} \mathrm{p}<0.05$ and

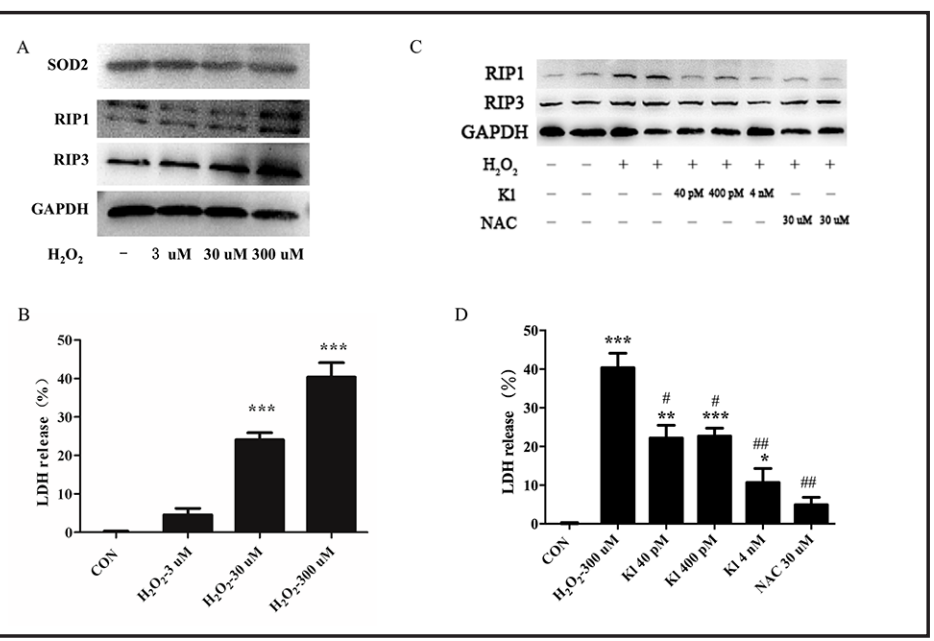
\#\# $\mathrm{p}<0.01$ vs. $\mathrm{H}_{2} \mathrm{O}_{2}-300 \mu \mathrm{M}$ group.

Klotho expression is downregulated and RIP3 activity is enhanced in AKI patients

Next, we tested whether human kidneys with AKI also display evidence of Klotho deficiency and RIP3 activation. The basic clinical information and profiles of AKI patients are shown in Tables 2 and 3, respectively. Immunofluorescence results showed that the expression levels of Klotho and SOD2 in the kidneys of AKI patients were markedly reduced 
Table 2. Baseline characteristics of studied population. AKI, acute kidney injury; Scr, serum creatinine; F, female; $\mathrm{M}$, male. ${ }^{* *} p<0.01$ vs. normal subjects

\begin{tabular}{lll}
\hline & $\begin{array}{l}\text { AKI } \\
(\mathrm{n}=10)\end{array}$ & $\begin{array}{l}\text { Normal individuals } \\
(\mathrm{n}=5)\end{array}$ \\
\hline Age (year) & $56.50 \pm 4.56$ & $66.80 \pm 1.16$ \\
Gender (F/M) & $4 / 6$ & $3 / 2$ \\
Scr (umol/L) & $362.3 \pm 69.10^{* *}$ & $82.00 \pm 7.52$ \\
\hline
\end{tabular}

compared with control kidneys (Fig. 8A). RIP3 was uniformly diffused throughout the cytosol of tubular cells in control kidneys in which Kim-1 expression were almost negative (Fig. 8B). However, it formed puncta and merged with Kim-1 protein in the kidneys of AKI patients.

\section{Discussion}

Our findings have several implications: (1) Klotho deficiency is not just a biomarker but a contributing factor to the development of AKI; (2) Klotho treatment effectively ameliorates AKI; (3) ROS is capable of triggering necroptosis in renal tubular epithelial cells, which are involved in the pathophysiology process of renal IRI; and (4) Klotho reduces necroptosis, presumably by targeting oxidative stress. To our knowledge, this is the first time that ROS has been proven to trigger necroptosis in renal tubular epithelial cells and that Klotho has been identified as a potential mediator of the necroptosis implicated in IRI-induced AKI.

Klotho is a multifunctional protein expressed predominantly in kidney tubular epithelium. In the context of AKI, we found an immediate but transient upregulation of serum Klotho at $0 \mathrm{~h}$ of reperfusion followed by a sustained and significant reduction from 5 h. The transient elevation of serum Klotho is presumed to be a defensive response to acute stress. Our data are in line with previous findings. Hu et al. showed decreased Klotho levels in the plasma and kidneys $3 \mathrm{~h}$ after reperfusion, earlier than the change in NGAL and Kim1 [20]. However, clinical studies of the time course of Klotho changes in humans remain lacking. Here, we examined the Klotho expression in kidney biopsy samples of AKI patients and controls and confirmed the downregulation of Klotho in AKI. A reduced Klotho level has been also found for other causes of AKI, such as cisplatin [22] and folic acid [33]. Thus, Klotho deficiency in AKI is a general phenomenon of kidney damage. Moreover, Klotho

Table 3. Clinical profile in AKI patients. AKI, acute crescentic glomerulonephritis; HSPN, Henoch-
chen injury; CKD, chronic kidney disease; CrGN, Schonlein purpura nephritis; MM, multiple myeloma; F, female; M, male

\begin{tabular}{|c|c|c|c|c|c|c|c|c|c|}
\hline \multirow[b]{2}{*}{ ID } & \multicolumn{9}{|c|}{ Potential contributors to AKI } \\
\hline & $\begin{array}{l}\text { Age } \\
\text { (years) }\end{array}$ & Gender & CKD & $\begin{array}{l}\text { Pre- } \\
\text { renal }\end{array}$ & CrGN & HSPN & $\begin{array}{l}\text { Nephro- } \\
\text { toxins }\end{array}$ & MM & AKI stages \\
\hline 1 & 61 & $\mathrm{~F}$ & & & + & & & & 3 \\
\hline 2 & 66 & M & & + & & + & & & 3 \\
\hline 3 & 50 & $\mathrm{~F}$ & + & + & & & & & 3 \\
\hline 4 & 66 & $\mathrm{~F}$ & & + & & & & & 2 \\
\hline 5 & 27 & $\mathrm{~F}$ & + & & & & & & 1 \\
\hline 6 & 63 & M & + & & & & & & 3 \\
\hline 7 & 35 & M & & & & & + & & 1 \\
\hline 8 & 66 & M & & & & & + & & 3 \\
\hline 9 & 66 & M & + & & & & & + & 3 \\
\hline 10 & 65 & M & & & + & & & & 1 \\
\hline
\end{tabular}

Fig. 8. Klotho is downregulated and RIP3 activity is enhanced in AKI patients. Representative immunofluorescence for (A) Klotho protein (green) merged with SOD2 (red) and (B) Kim-1 protein (green) merged with RIP3 protein (red) in kidney samples of normal individuals (top panels, $n=5$ ) and of AKI patients (bottom panels, $n=10$ ).

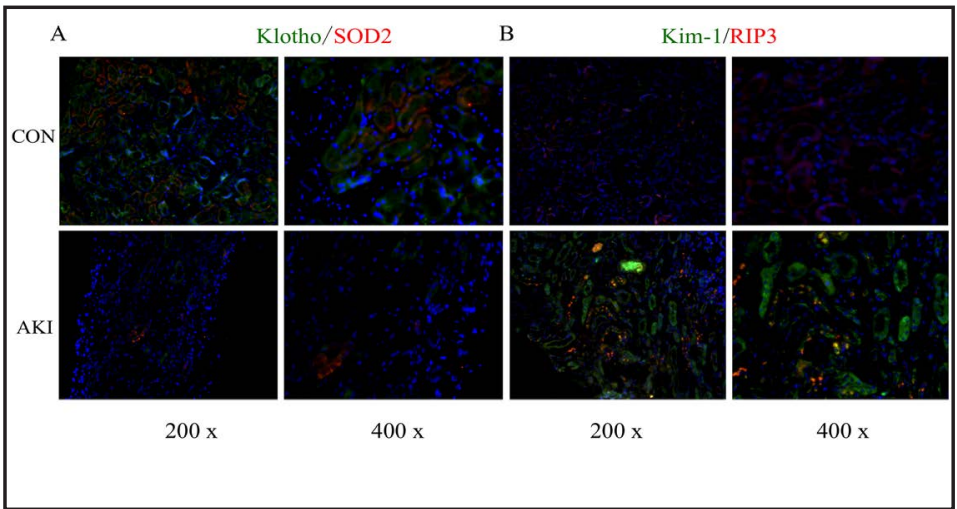


haploinsufficient $\left(\mathrm{Kl}^{+} /-\right)$mice develop more severe renal dysfunction and more extensive histological abnormalities than wild-type mice after renal IRI [20]. Klotho loss can induce renal apoptosis and calcification [34]. In the current study, Klotho replacement effectively ameliorated AKI (Fig. 2). These findings strongly indicate a pathogenic role of Klotho loss in AKI.

Few studies have assessed the performance of urinary Klotho in AKI. Here, we found an acute and transient increase in urinary Klotho in AKI mice, which recovered soon thereafter. Our data are in agreement with the results of Torregrosa et al., who showed an early elevation in urinary Klotho levels in AKI patients after cardiac surgery through ELISA [35]. However, Hu et al. demonstrated reduced urinary levels of Klotho with immunoblotting, without providing the sample collection time [20]. Physiologically, Klotho is present in the urine, which can be hematogenously derived through transcytosis and can also be secreted by in situ cells rather than glomerular filtration $[17,18,36]$. However, we do not know the changes in the tubular secretory action for Klotho during AKI. Histologically, proximal tubular epithelial cells lose their brush border membrane, compatible with cell necrosis and shedding. This pathological process may result in an acute increase in Klotho shedding to the lumen (Fig. 1G). Therefore, the transient elevation in urinary Klotho levels may indicate the severity of tubular injury during AKI.

AKI is histologically characterized by degeneration, necrosis, and accompanying inflammation. In recent years, major breakthroughs have shed light on the mechanism of necroptosis and its in vivo relevance. In 2000, Holler et al. found that RIP1 was required for FAS ligand-induced caspase-independent cell death [37], which was later termed necroptosis [13]. Another member of the RIPK family, RIP3, which interacts with RIP1 and forms the necroptosome, is a key signaling molecule for the occurrence of necroptosis [10]. Recently, this process has been revealed to be responsible for the pathophysiology of IRI in several organs, including the myocardium [11] and brain [13]. In 2011, Linkermann and his colleagues showed a protection action of Nec-1 on renal IRI in an animal model [38]. Later, RIP3 gene deletion was demonstrated to protect mice from IRI or cisplatin-induced AKI and kidney transplant injury [39-41]. In the present study, we further showed using in vivo and in vitro approaches an increased aggregated pattern of RIP3 in AKI patients and demonstrated that necroptosis is critical to the pathophysiological process of renal IRI (Figs. 3 and 4). The importance of the involvement of necroptosis in AKI suggested by the present and previous observations raise a question as to what triggers necroptosis in tubular epithelial cells during AKI.

Numerous lines of evidence have suggested a critical role for ROS in mediating necroptosis, which seems cell type-dependent $[42,43]$. ROS is capable of inducing necroptosis in several cell types, such as cardiomyocytes [11,44], HeLa cells [45], and endothelial cells [46], but not in HT-29 cells [47] or THP-1 cells [48]. We showed increased oxidative stress accompanied by greater necroptosis in AKI mice, implying a possible link between ROS and necroptotic cell death during AKI. In renal tubular epithelial cells, we are the first to illuminate the critical role of ROS in triggering necroptosis by showing that ROS scavenger dramatically reduces $\mathrm{H} / \mathrm{R}$ - or $\mathrm{H}_{2} \mathrm{O}_{2}$-induced TCMK-1 cell necroptotic death. Previous studies with gene silencing or chemical inhibitors targeting the mitochondrial complex or NADPH complex revealed an important role for ROS from mitochondria in modulating necroptosis [46, 49]. Although the underlying pathways for this process in AKI are unclear, the involvement of ROS in triggering necroptosis in tubular epithelial cells opens a new perspective to mitigate this regulated cell death in AKI.

The effects of Klotho on cellular health have been well documented [16, 50-56]. Our results are in agreement with previous studies showing that Klotho treatment is sufficient to attenuate AKI $[20,22]$. However, the mechanism is far from fully understood and it is currently unclear whether Klotho plays a functional role in necroptosis. Previous studies have suggested an anti-apoptotic effect of Klotho, mainly evidenced by TUNEL staining $[57,58]$. However, TUNEL positivity, representing double-strand breaks, can also arise in regulated necrosis [31,32]. Moreover, HSP70, the reported molecular target of Klotho to interfere with 
apoptosis, also protects against necroptosis in cardiomyocytes [59]. Thus, Klotho may play a functional role in necroptosis. In the present study, we found that Klotho therapy reduced the expression of RIP1, RIP3, and IL-1 beta and decreased the amounts of TUNEL-positive cells in AKI mice. Likewise, Klotho protected TCMK-1 cells from H/R- or $\mathrm{H}_{2} \mathrm{O}_{2}$-induced necroptosis. These observations indicated that Klotho might mediate necroptosis during IRI-induced AKI.

In 2005, Yamamoto et al. revealed that transgenic mice with Klotho overexpression had higher expression of MnSOD, which was attributable to its suppression of insulin/IGF$1 /$ FoxOs signaling $[60,61]$. Recently, Lim et al. also showed a protective role of Klotho in tacrolimus-induced oxidative stress via FoxO3a-mediated SOD2 expression [62]. In the present study, we demonstrated an anti-oxidant role of Klotho during renal IRI, indicated by decreased levels of u-8-OHdG, renal MDA, and 3-nitrotyrosine with increased SOD activities and SOD2 expression after Klotho treatment. In vitro, we also found reduced ROS formation and elevated SOD2 expression in the Klotho-treated group under H/R. However, the effects of Klotho on the expression of catalase and GPX4 are weak. We further showed that Klotho inhibited the phosphorylation of FoxO1 and FoxO3a in response to H/R. Activated FoxO transcription factors can target SOD2 promoter and thus increase its expression [63]. Although Klotho plays an important role in FGF23 signaling [16], we found no significant difference in FGF23 transcripts between sham and IRI mice and also no significant difference between Klotho treatment and non-treatment IRI groups. The repression of oxidative stress by Klotho makes it possible that Klotho ameliorates IRI-induced necroptosis by reducing ROS generation. In support of this, Klotho administration significantly attenuated $\mathrm{H}_{2} \mathrm{O}_{2}$-induced necroptosis (Fig. 7). Taken together, the results of this study allow us to safely conclude that Klotho plays an important role in regulating necroptosis in tubular epithelial cells during renal IRI, which depends, at least partly, on the suppression of oxidative stress.

\section{Conclusion}

In summary, Klotho deficiency is a general phenomenon in AKI and Klotho treatment protects renal tubular epithelial cells from IRI injury. This protection may be associated with anti-necroptotic effects by targeting the oxidative stress that can trigger necroptotic cell death in AKI. These results suggest that therapeutic Klotho delivery would be a feasible strategy to mitigate AKI.

\section{Acknowledgements}

This study was supported by the National Natural Science Foundation of China (No. 81170678, No. 81470918), Natural Science Foundation of Shanghai (No. 15ZR1425900), Shanghai Science and Technology Commission (No. 17695840500), Scientific Research Foundation for Shanghai Municipal Commission of Health and Family Planning (No. 20134095), and Scientific Research Foundation for the Returned Overseas Chinese Scholars.

\section{Disclosure Statement}

The authors declare no conflict of interests.

\section{References}

1 Kaddourah A, Basu RK, Bagshaw SM, Goldstein SL, Investigators A: Epidemiology of Acute Kidney Injury in Critically Ill Children and Young Adults. N Engl J Med 2017;376:11-20. 


\section{Cellular Physiology Cell Physiol Biochem 2018;45:2268-2282

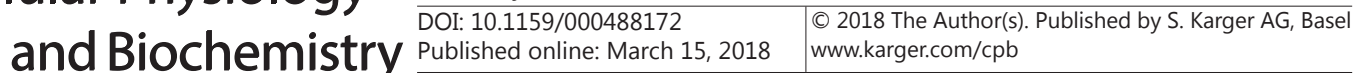

2 Lewington AJ, Cerda J, Mehta RL: Raising awareness of acute kidney injury: a global perspective of a silent killer. Kidney Int 2013;84:457-467.

-3 Susantitaphong P, Cruz DN, Cerda J, Abulfaraj M, Alqahtani F, Koulouridis I, Jaber BL, Acute Kidney Injury Advisory Group of the American Society of N: World incidence of AKI: a meta-analysis. Clin J Am Soc Nephrol 2013;8:1482-1493.

-4 Lameire NH, Bagga A, Cruz D, De Maeseneer J, Endre Z, Kellum JA, Liu KD, Mehta RL, Pannu N, Van Biesen W, Vanholder R: Acute kidney injury: an increasing global concern. Lancet 2013;382:170-179.

-5 Basile DP, Bonventre JV, Mehta R, Nangaku M, Unwin R, Rosner MH, Kellum JA, Ronco C, Group AXW: Progression after AKI: Understanding Maladaptive Repair Processes to Predict and Identify Therapeutic Treatments. J Am Soc Nephrol 2016;27:687-697.

6 Wald R, Quinn RR, Luo J, Li P, Scales DC, Mamdani MM, Ray JG, University of Toronto Acute Kidney Injury Research G: Chronic dialysis and death among survivors of acute kidney injury requiring dialysis. JAMA 2009;302:1179-1185.

7 Linkermann A, Chen G, Dong G, Kunzendorf U, Krautwald S, Dong Z: Regulated cell death in AKI. J Am Soc Nephrol 2014;25:2689-2701.

8 Linkermann A, Green DR: Necroptosis. N Engl J Med 2014;370:455-465.

$>9$ Cho YS, Challa S, Moquin D, Genga R, Ray TD, Guildford M, Chan FK: Phosphorylation-driven assembly of the RIP1-RIP3 complex regulates programmed necrosis and virus-induced inflammation. Cell 2009;137:11121123.

10 Zhang DW, Shao J, Lin J, Zhang N, Lu BJ, Lin SC, Dong MQ Han J: RIP3, an energy metabolism regulator that switches TNF-induced cell death from apoptosis to necrosis. Science 2009;325:332-336.

11 Zhang T, Zhang Y, Cui M, Jin L, Wang Y, Lv F, Liu Y, Zheng W, Shang H, Zhang J, Zhang M, Wu H, Guo J, Zhang $\mathrm{X}, \mathrm{Hu}$ X, Cao CM, Xiao RP: CaMKII is a RIP3 substrate mediating ischemia- and oxidative stress-induced myocardial necroptosis. Nat Med 2016;22:175-182.

12 Liu J, Wu P, Wang H, Wang Y, Du Y, Cheng W, Xu Z, Zhou N, Wang L, Yang Z: Necroptosis Induced by AdHGF Activates Endogenous C-Kit+ Cardiac Stem Cells and Promotes Cardiomyocyte Proliferation and Angiogenesis in the Infarcted Aged Heart. Cell Physiol Biochem 2016;40:847-860.

13 Degterev A, Huang Z, Boyce M, Li Y, Jagtap P, Mizushima N, Cuny GD, Mitchison TJ, Moskowitz MA, Yuan J: Chemical inhibitor of nonapoptotic cell death with therapeutic potential for ischemic brain injury. Nat Chem Biol 2005;1:112-119.

14 Xu Y, Han J: The Necrosome in Acute Kidney Injury. Semin Nephrol 2016;36:199-207.

15 Kuro-o M, Matsumura Y, Aizawa H, Kawaguchi H, Suga T, Utsugi T, Ohyama Y, Kurabayashi M, Kaname T, Kume E, Iwasaki H, Iida A, Shiraki-Iida T, Nishikawa S, Nagai R, Nabeshima YI: Mutation of the mouse klotho gene leads to a syndrome resembling ageing. Nature 1997;390:45-51.

16 Xu Y, Sun Z: Molecular basis of Klotho: from gene to function in aging. Endocr Rev 2015;36:174-193.

17 Hu MC, Shi M, Zhang J, Addo T, Cho HJ, Barker SL, Ravikumar P, Gillings N, Bian A, Sidhu SS, Kuro-o M, Moe OW: Renal Production, Uptake, and Handling of Circulating alphaKlotho. J Am Soc Nephrol 2016;27:79-90.

18 Lindberg K, Amin R, Moe OW, Hu MC, Erben RG, Ostman Wernerson A, Lanske B, Olauson H, Larsson TE: The kidney is the principal organ mediating klotho effects. J Am Soc Nephrol 2014;25:2169-2175.

19 Asai O, Nakatani K, Tanaka T, Sakan H, Imura A, Yoshimoto S, Samejima K, Yamaguchi Y, Matsui M, Akai Y, Konishi N, Iwano M, Nabeshima Y, Saito Y: Decreased renal alpha-Klotho expression in early diabetic nephropathy in humans and mice and its possible role in urinary calcium excretion. Kidney Int 2012;81:539-547.

20 Hu MC, Shi M, Zhang J, Quinones H, Kuro-o M, Moe OW: Klotho deficiency is an early biomarker of renal ischemia-reperfusion injury and its replacement is protective. Kidney Int 2010;78:1240-1251.

-21 Lin W, Zhang Q, Liu L, Yin S, Liu Z, Cao W: Klotho restoration via acetylation of Peroxisome ProliferationActivated Receptor gamma reduces the progression of chronic kidney disease. Kidney Int 2017

22 Panesso MC, Shi M, Cho HJ, Paek J, Ye J, Moe OW, Hu MC: Klotho has dual protective effects on cisplatininduced acute kidney injury. Kidney Int 2014;85:855-870.

23 Takenaka T, Inoue T, Miyazaki T, Kobori H, Nishiyama A, Ishii N, Hayashi M, Suzuki H: Klotho suppresses the renin-angiotensin system in adriamycin nephropathy. Nephrol Dial Transplant 2017;32:791-800.

24 Wang Y, Sun Z: Klotho gene delivery prevents the progression of spontaneous hypertension and renal damage. Hypertension 2009;54:810-817. 


\section{Cellular Physiology Cell Physiol Biochem 2018;45:2268-2282 \begin{tabular}{ll|l} 
and Biochemistry Published onlIne: March 15, 2018 & $\begin{array}{l}\text { (c) } 2018 \text { The Author(s). Published by S. Karger AG, Basel } \\
\text { www.karger.com/cpb }\end{array}$
\end{tabular}}

25 Mehta RL, Kellum JA, Shah SV, Molitoris BA, Ronco C, Warnock DG, Levin A, Acute Kidney Injury N: Acute Kidney Injury Network: report of an initiative to improve outcomes in acute kidney injury. Crit Care 2007;11:R31.

26 Chiao H, Kohda Y, McLeroy P, Craig L, Housini I, Star RA: Alpha-melanocyte-stimulating hormone protects against renal injury after ischemia in mice and rats. J Clin Invest 1997;99:1165-1172.

27 Guan X, Qian Y, Shen Y, Zhang L, Du Y, Dai H, Qian J, Yan Y: Autophagy protects renal tubular cells against ischemia / reperfusion injury in a time-dependent manner. Cell Physiol Biochem 2015;36:285-298.

-28 Schmittgen TD, Livak KJ: Analyzing real-time PCR data by the comparative C(T) method. Nat Protoc 2008;3:1101-1108.

29 Freitas MC, Uchida Y, Lassman C, Danovitch GM, Busuttil RW, Kupiec-Weglinski JW: Type I interferon pathway mediates renal ischemia/reperfusion injury. Transplantation 2011;92:131-138.

30 Pasparakis M, Vandenabeele P: Necroptosis and its role in inflammation. Nature 2015;517:311-320.

- 31 Vanden Berghe T, Grootjans S, Goossens V, Dondelinger Y, Krysko DV, Takahashi N, Vandenabeele P: Determination of apoptotic and necrotic cell death in vitro and in vivo. Methods 2013;61:117-129.

-32 Weinlich R, Oberst A, Dillon CP, Janke LJ, Milasta S, Lukens JR, Rodriguez DA, Gurung P, Savage C, Kanneganti TD, Green DR: Protective roles for caspase-8 and cFLIP in adult homeostasis. Cell Rep 2013;5:340-348.

33 Moreno JA, Izquierdo MC, Sanchez-Nino MD, Suarez-Alvarez B, Lopez-Larrea C, Jakubowski A, Blanco J, Ramirez R, Selgas R, Ruiz-Ortega M, Egido J, Ortiz A, Sanz AB: The inflammatory cytokines TWEAK and TNFalpha reduce renal klotho expression through NFkappaB. J Am Soc Nephrol 2011;22:1315-1325.

34 Ohnishi M, Razzaque MS: Dietary and genetic evidence for phosphate toxicity accelerating mammalian aging. FASEB J 2010;24:3562-3571.

-35 Torregrosa I, Montoliu C, Urios A, Gimenez-Garzo C, Tomas P, Solis MA, Ramos C, Juan I, Puchades MJ, Saez G, Blasco ML, Miguel A: Urinary Klotho measured by ELISA as an early biomarker of acute kidney injury in patients after cardiac surgery or coronary angiography. Nefrologia 2015;35:172-178.

-36 Hu MC, Shi M, Zhang J, Pastor J, Nakatani T, Lanske B, Razzaque MS, Rosenblatt KP, Baum MG, Kuro-o M, Moe OW: Klotho: a novel phosphaturic substance acting as an autocrine enzyme in the renal proximal tubule. FASEB J 2010;24:3438-3450.

37 Holler N, Zaru R, Micheau O, Thome M, Attinger A, Valitutti S, Bodmer JL, Schneider P, Seed B, Tschopp J: Fas triggers an alternative, caspase-8-independent cell death pathway using the kinase RIP as effector molecule. Nat Immunol 2000;1:489-495.

-38 Linkermann A, Brasen JH, Himmerkus N, Liu S, Huber TB, Kunzendorf U, Krautwald S: Rip1 (receptorinteracting protein kinase 1) mediates necroptosis and contributes to renal ischemia/reperfusion injury. Kidney Int 2012;81:751-761.

-39 Linkermann A, Brasen JH, Darding M, Jin MK, Sanz AB, Heller JO, De Zen F, Weinlich R, Ortiz A, Walczak H, Weinberg JM, Green DR, Kunzendorf U, Krautwald S: Two independent pathways of regulated necrosis mediate ischemia-reperfusion injury. Proc Natl Acad Sci U S A 2013;110:12024-12029.

40 Xu Y, Ma H, Shao J, Wu J, Zhou L, Zhang Z, Wang Y, Huang Z, Ren J, Liu S, Chen X, Han J: A Role for Tubular Necroptosis in Cisplatin-Induced AKI. J Am Soc Nephrol 2015;26:2647-2658.

-41 Lau A, Wang S, Jiang J, Haig A, Pavlosky A, Linkermann A, Zhang ZX, Jevnikar AM: RIPK3-mediated necroptosis promotes donor kidney inflammatory injury and reduces allograft survival. Am J Transplant 2013;13:2805-2818.

-42 Radogna F, Cerella C, Gaigneaux A, Christov C, Dicato M, Diederich M: Cell type-dependent ROS and mitophagy response leads to apoptosis or necroptosis in neuroblastoma. Oncogene 2016;35:3839-3853.

43 Fulda S: Regulation of necroptosis signaling and cell death by reactive oxygen species. Biol Chem 2016;397:657-660.

44 Liang W, Chen M, Zheng D, Li J, Song M, Zhang W, Feng J, Lan J: The Opening of ATP-Sensitive K+ Channels Protects H9c2 Cardiac Cells Against the High Glucose-Induced Injury and Inflammation by Inhibiting the ROS-TLR4-Necroptosis Pathway. Cell Physiol Biochem 2017;41:1020-1034.

45 Zhang Y, Su SS, Zhao S, Yang Z, Zhong CQ Chen X, Cai Q, Yang ZH, Huang D, Wu R, Han J: RIP1 autophosphorylation is promoted by mitochondrial ROS and is essential for RIP3 recruitment into necrosome. Nat Commun 2017;8:14329.

46 Zhao W, Feng H, Sun W, Liu K, Lu JJ, Chen X: Tert-butyl hydroperoxide (t-BHP) induced apoptosis and necroptosis in endothelial cells: Roles of NOX4 and mitochondrion. Redox Biol 2017;11:524-534. 


\section{Cellular Physiology Cell Physiol Biochem 2018;45:2268-2282

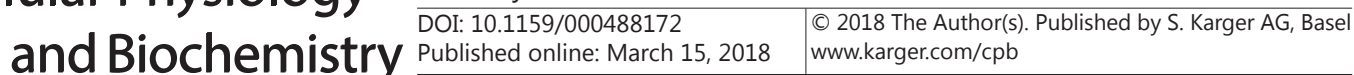 \\ Quian et al.: Klotho Reduces Necroptosis}

47 He S, Wang L, Miao L, Wang T, Du F, Zhao L, Wang X: Receptor interacting protein kinase-3 determines cellular necrotic response to TNF-alpha. Cell 2009;137:1100-1111.

-48 Temkin V, Huang Q Liu H, Osada H, Pope RM: Inhibition of ADP/ATP exchange in receptor-interacting protein-mediated necrosis. Mol Cell Biol 2006;26:2215-2225.

49 Vanlangenakker N, Vanden Berghe T, Bogaert P, Laukens B, Zobel K, Deshayes K, Vucic D, Fulda S, Vandenabeele P, Bertrand MJ: cIAP1 and TAK1 protect cells from TNF-induced necrosis by preventing RIP1/RIP3-dependent reactive oxygen species production. Cell Death Differ 2011;18:656-665.

50 Mencke R, Hillebrands JL, consortium N: The role of the anti-ageing protein Klotho in vascular physiology and pathophysiology. Ageing Res Rev 2017;35:124-146.

51 Hum JM, O’Bryan LM, Tatiparthi AK, Cass TA, Clinkenbeard EL, Cramer MS, Bhaskaran M, Johnson RL, Wilson JM, Smith RC, White KE: Chronic Hyperphosphatemia and Vascular Calcification Are Reduced by Stable Delivery of Soluble Klotho. J Am Soc Nephrol 2017;28:1162-1174.

52 Lin Y, Sun Z: Antiaging Gene Klotho Attenuates Pancreatic beta-Cell Apoptosis in Type 1 Diabetes. Diabetes 2015;64:4298-4311.

53 Shin IS, Shin HK, Kim JC, Lee MY: Role of Klotho, an antiaging protein, in pulmonary fibrosis. Arch Toxicol 2015;89:785-795.

54 Zhou L, Li Y, Zhou D, Tan RJ, Liu Y: Loss of Klotho contributes to kidney injury by derepression of Wnt/betacatenin signaling. J Am Soc Nephrol 2013;24:771-785.

55 Hu MC, Moe OW: Klotho as a potential biomarker and therapy for acute kidney injury. Nat Rev Nephrol 2012;8:423-429.

56 Abousaab A, Warsi J, Salker MS, Lang F: beta-Klotho as a Negative Regulator of the Peptide Transporters PEPT1 and PEPT2 Cell Physiol Biochem 2016;40:874-882.

57 Sugiura H, Yoshida T, Mitobe M, Yoshida S, Shiohira S, Nitta K, Tsuchiya K: Klotho reduces apoptosis in experimental ischaemic acute kidney injury via HSP-70 ～Nephrol Dial Transplant 2010;25:60-68.

58 Sugiura H, Yoshida T, Tsuchiya K, Mitobe M, Nishimura S, Shirota S, Akiba T, Nihei H: Klotho reduces apoptosis in experimental ischaemic acute renal failure. Nephrol Dial Transplant 2005;20:2636-2645.

59 Liu X, Zhang C, Zhang C, Li J, Guo W, Yan D, Yang C, Zhao J, Xia T, Wang Y, Xu R, Wu X, Shi J: Heat shock protein 70 inhibits cardiomyocyte necroptosis through repressing autophagy in myocardial ischemia/ reperfusion injury. In vitro Cell Dev Biol Anim 2016;52:690-698.

60 Jin J, Jin L, Lim SW, Yang CW: Klotho Deficiency Aggravates Tacrolimus-Induced Renal Injury via the Phosphatidylinositol 3-Kinase-Akt-Forkhead Box Protein O Pathway. Am J Nephrol 2016;43:357-365.

61 Yamamoto M, Clark JD, Pastor JV, Gurnani P, Nandi A, Kurosu H, Miyoshi M, Ogawa Y, Castrillon DH, Rosenblatt KP, Kuro-o M: Regulation of oxidative stress by the anti-aging hormone klotho. J Biol Chem 2005;280:38029-38034.

62 Lim SW, Jin L, Luo K, Jin J, Shin YJ, Hong SY, Yang CW: Klotho enhances FoxO3-mediated manganese superoxide dismutase expression by negatively regulating PI3K/AKT pathway during tacrolimus-induced oxidative stress. Cell Death Dis 2017;8:e2972.

63 Eijkelenboom A, Burgering BM: FOXOs: signalling integrators for homeostasis maintenance. Nat Rev Mol Cell Biol 2013;14:83-97. 